\title{
Correction to: Unmet need for family planning services among young married women (15-24 years) living in urban slums of India
}

Kriti Yadav ${ }^{{ }^{*}}$, Monika Agarwal $^{2}$, Mukesh Shukla ${ }^{3}$, Jai Vir Singh ${ }^{4}$ and Vijay Kumar Singh ${ }^{2}$

\section{Correction to: BMC Womens Health (2020) 21:46 https://doi.org/10.1186/s12905-020-01010-9}

Following publication of the original article [1], we were notified of an error in the affiliation of the first author Kriti Yadav:

Incorrect affiliation:

- Assistant Professor, Vir Chandra Singh Garhwali Government Institute of Medical Science and Research, Srinagar, Pauri Garhwal, Uttarakhand, India

Correct affiliation:

- MD, Senior Resident, Department of Community \& Family Medicine, All India Institute of Medical Sciences, Bhopal, MP, India.

\section{Author details}

'Department of Community \& Family Medicine, All India Institute of Medical Sciences, Bhopal, MP, India. ${ }^{2}$ Department of Community Medicine \& Public Health, K.G. Medical University, Lucknow, UP, India. ${ }^{3}$ Vir Chandra Singh Garhwali Government Institute of Medical Science and Research, Srinagar, Pauri Garhwal, Uttarakhand, India. ${ }^{4}$ Hind Institute of Medical Sciences, Lucknow, UP, India.
Published online: 24 September 2020

\section{Reference}

1. Yadav $\mathrm{K}$, et al. Unmet need for family planning services among young married women (15-24 years) living in urban slums of India. BMC Womens Health. 2020;21:46. https://doi.org/10.1186/s12905-020-01010-9.

The original article can be found online at https://doi.org/10.1186/s12905020-01010-9.

* Correspondence: drkritiyadav18@gmail.com

'Department of Community \& Family Medicine, All India Institute of Medical Sciences, Bhopal, MP, India

Full list of author information is available at the end of the article

(C) The Author(s). 2020 Open Access This article is licensed under a Creative Commons Attribution 4.0 International License, which permits use, sharing, adaptation, distribution and reproduction in any medium or format, as long as you give appropriate credit to the original author(s) and the source, provide a link to the Creative Commons licence, and indicate if changes were made. The images or other third party material in this article are included in the article's Creative Commons licence, unless indicated otherwise in a credit line to the material. If material is not included in the article's Creative Commons licence and your intended use is not permitted by statutory regulation or exceeds the permitted use, you will need to obtain permission directly from the copyright holder. To view a copy of this licence, visit http://creativecommons.org/licenses/by/4.0/ The Creative Commons Public Domain Dedication waiver (http://creativecommons.org/publicdomain/zero/1.0/) applies to the data made available in this article, unless otherwise stated in a credit line to the data. 